\title{
RESPONSE OF EUROPEAN BREAD WHEAT TO DIFFERENT VERNALIZATION TREATMENTS UNDER THE ENVIRONMENTAL CONDITIONS OF KURDISTAN-IRAQ
}

\author{
Ahmad, N. S. - Abdulqadir, S. H. - Ali, S. H. S. ${ }^{*}$ Muhammad, A. G. - Ahmad, M. M. \\ Biotechnology and Crop Science Department, College of Agricultural Engineering Sciences, \\ University of Sulaimani, Sulaimani, Iraq \\ *Corresponding author \\ e-mail: sarkawt.ali@univsul.edu.iq \\ (Received 26 $6^{\text {th }}$ Mar 2020; accepted $9^{\text {th }}$ Jul 2020)
}

\begin{abstract}
A factorial experiment was conducted in Kurdistan-Iraq to identify responses of European wheat varieties to vernalization treatments at $22^{\circ} \mathrm{C}, 4^{\circ} \mathrm{C}$ and $-18^{\circ} \mathrm{C}$ for two and four weeks in a Complete Randomized Block Design (CRBD) experiment with three replicates. Sabir-beg had the highest and most desired performance for most of the traits studied including grain yield. The highest spike and grain number were recorded for Hereford and Skalnige, respectively. Incubation temperatures had highly significant effects on most of the traits, including grain yield. Two weeks-vernalization at low temperature is satisfactory for vernalization of these wheat varieties. The interaction between varieties and incubation temperature produced varying effects. Grain number is mainly genotype-related. Sabir-beg $\times$ two weeks incubations had spent minimum days to flowering, followed by days to maturity. The varieties were persistent in their interaction with the incubation period. The interaction effect of $4^{\circ} \mathrm{C} \times$ four weeks incubation advanced flowering, extending flowering-maturation period to give a higher spike number. Harvest index, biomass, and grain yield were highly significant for both interactions of varieties $\times$ incubation temperature and varieties $\times$ incubation period. The three-factors interaction had a highly significant effect on most traits. The wheat varieties can be developed with more predictable responses to in vitro vernalization as an alternative to early sowing.
\end{abstract}

Keywords: variety, in vitro, low temperature, VRN gene, grain yield

\section{Introduction}

One of the critical stages in plant development is flowering, that affects crop production. The stage of crop vegetative/reproductive transition is a combination of plant responses to the environment including stresses (Kazan and Lyons, 2014). Optimal products can be obtained by the management of these stages. The time to flowering must coincide with favorable conditions to guarantee the species survival via producing viable seeds. Vernalization, a prolonged period of low temperature, is one of the environmental stimuli that is required to initiate flowering (Michaels, 2009; Dixon et al., 2019). Vernalization, as a plant cue, is required to transit the plant to reproductive stages, which means shifting from the vegetative growth to flowering and seed production (Trevaskis, 2010; Woods et al., 2019). This phenomenon is promoted by a chilling treatment (Chouard, 1960; Muterko and Salina, 2018). The effect of vernalization is to reduce the production period of leaf primordia (Griffiths et al., 1985), and consequently reduce the number of leaves and the tillers initiated on the main shoot (Gott et al., 1955; Levy and Peterson, 1972).

Winter cereals have a quantitative vernalization requirement for flowering (Woods et al., 2019). It has been identified that vernalized plants are more prone to flower earlier than non-vernalized (Robertson et al., 1996). Winter wheat genotypes grown under temperate regions can be vernalized at a seedling stage or even at full grain maturity, during the chilling period of winter $\left(<4^{\circ} \mathrm{C}\right)$ (Clay et al., 2012; Mureşan et al., 2019). 
Bread wheat is one of the most cultivated grain crops occupying a wide range of lands worldwide, its winter varieties are planted in the autumn and they have adequate tolerance to survive freezing temperatures in winter. This adaptation occurs due to the reduction of moisture content and the accumulation of soluble carbohydrates in the crown area of the wheat plant, causing the reduction in growth rate at this stage, providing the plant resistance to frost temperature (Clay et al., 2012). Hence winter wheat varieties usually have higher yield potential than spring varieties planted later in the spring because of their longer growing period and vernalization explosion (Galiba et al., 2009; Li et al., 2013). Response to vernalization is one of the most important factors affecting environmental adaptation of wheat (Wang et al., 1995; Whittal et al., 2018). This action has been found to be under the effect of three genes of VRN1, VRN2, andVRN3, as a major gene for the vernalization in winter wheat. This was mapped using a population of recombinant inbred lines (RILs) generated from two winter wheat cultivars (Yan et al., 2006, 2015). After exposing the plants to non-freezing temperature for certain periods of time the coldresponsive genes are activated (Armonienè et al., 2013). Based on the exposing period of cold temperature to promote flowering on time, winter wheat has three categories; a weak winter type requires less than two weeks, a semi-winter type requires 2-4 weeks exposing of low temperature for flowering: while a strong type requires longer cold exposure (4 weeks and more) for timely flowering (Crofts, 1989). Flowering in wheat occurs after all main-stem leaves have appeared and are fully expanded. It is the consequence of the rate of leaf appearance which is controlled mostly by the temperature of the apical meristem and leaf expansion zones (McMaster and Wilhelm, 2003). Triticum aestivum L. (wheat, $2 \mathrm{n}=6 \mathrm{x}=42$ ) is known to be cultivated across the most variable land area than any other grain crop (Rozbicki et al., 2019).

Vernalization requirement of winter wheat varies according to their genetic construction (Whittal et al., 2018). Varieties obtain sufficient vernalization when sown at an early time in autumn, while in case of late sowing with any reason, varieties will not start flowering on time (Mureşan et al., 2019), making the plant to have reduced flower or have late initiation, making the yield to be reduced quantitatively and qualitatively. The objective of this study was to identify the response of winter wheat varieties to different vernalization treatments in the control environment before planting, aiming at establishing the latest safe sowing date for winter wheat varieties, with a reasonable yield.

\section{Materials and methods}

A factorial experiment was conducted in the experimental field of the College of Agricultural Engineering Sciences, University of Sulaimani, Kurdistan of Iraq, located at Lat. 35 34' 307"; N, Long. 45 21' 992"; E, $765 \mathrm{~m}$ asl. CRBD experiment was conducted for five varieties, four European and one local variety (factor A), see Table 1.

Grains were treated with three different temperatures, namely at room temperature $\left(22^{\circ} \mathrm{C}\right.$ ), at laboratory condition, $4^{\circ} \mathrm{C}$ (in a refrigerator) and at $-18^{\circ} \mathrm{C}$, in a freezer (factor $\mathrm{B}$ ), for two different periods of two and four weeks (factor C). The incubation started on $12^{\text {th }}$ November 2018 for four weeks incubation and on $27^{\text {th }}$ November 2018 for two weeks incubation, to be directly sown on $12^{\text {th }}$ December after termination of the designated period, see metrological data in Table 2. All treatment combination were sown in three replicates. Each replicate was applied on an area of $0.60 \mathrm{~m}^{2}$, planting was performed on lines of two-meter length, distanced $30 \mathrm{~cm}$ between the lines, and $50 \mathrm{~cm}$ between replications. 
Table 1. Names and the sources of five wheat varieties used in the study

\begin{tabular}{c|c|c|c}
\hline No. & Name & Pedigree/origin & Source \\
\hline 1 & Mariboss & Denmark & DCA - Danish Centre For Food And Agriculture, Aarhus University \\
2 & Skalnige & Denmark & DCA - Danish Centre For Food And Agriculture, Aarhus University \\
3 & Hereford & Denmark & DCA - Danish Centre For Food And Agriculture, Aarhus University \\
4 & Ritraw & Denmark & DCA - Danish Centre For Food And Agriculture, Aarhus University \\
5 & Sabir-beg & Local variety, Iraq & Bakrajo research Station, Sulaimani, Iraq \\
\hline
\end{tabular}

Table 2. Meteorological data of Sulaimani-Iraq for the growing season 2018-2019

\begin{tabular}{c|ccc|c}
\hline \multirow{2}{*}{ Month } & \multicolumn{3}{|c|}{ Temperature } & \multirow{2}{*}{$\begin{array}{c}\text { Rainfall } \\
(\mathbf{m m})\end{array}$} \\
\cline { 2 - 4 } & Min. Temp. $\left(\mathbf{C}^{\circ}\right)$ & Max. Temp. $\left(\mathbf{C}^{\circ}\right)$ & Average Temp. $\left(\mathbf{C}^{\circ}\right)$ & 48.2 \\
October 2018 & 9.6 & 32.0 & 19.2 & 99.8 \\
November 2018 & 6.2 & 22.0 & 12.6 & 281.8 \\
December 2018 & -2.6 & 15.0 & 5.2 & 210.6 \\
January 2019 & 0.8 & 13.8 & 5.4 & 108.2 \\
February 2019 & -2.0 & 17.4 & 6.8 & 248.6 \\
March 2019 & 1.6 & 21.2 & 10.8 & 190.0 \\
April 2019 & 2.4 & 26.0 & 13.2 & 28.4 \\
May 2019 & 12.8 & 33.8 & 17.6 & 1215.6 \\
\hline Total rainfall (mm) & \multicolumn{3}{|}{} \\
\hline
\end{tabular}

The land was tilled twice, smoothed, and plots were prepared before sowing. The varieties were sown on $12^{\text {th }}$ December 2018 containing 30 treatment combinations in which they were homogenous experimental units. Grains size from all varieties was unified by sieving, to obtain persistent population density in the field. After incubation treatment for designated periods, the grains were planted within the lines for all replicates. Each replicate consisted of $3.5 \mathrm{~g}$ with uniform size.

The recommended doses of $80 \mathrm{~kg} \mathrm{~N} / \mathrm{ha}$ and $80 \mathrm{~kg} \mathrm{P}_{2} \mathrm{O}_{5} / \mathrm{ha}$ were applied for the experiment and all other agricultural practices were conducted as required. There was no chemical application (herbicide, herbicide, or pesticide) for the treatments, and the experiment was run under rainfed condition. Some physical and chemical properties of the experimental soil are given in Table 3.

Table 3. Physical and chemical properties of the studied soil

\begin{tabular}{c|c|c|c|c|c|c|c|c|c|c}
\hline $\begin{array}{c}\text { Soil } \\
\text { properties }\end{array}$ & $\begin{array}{c}\text { Soil } \\
\text { texture } \\
(\text { P.S.D) }\end{array}$ & $\begin{array}{c}\text { Sand } \\
\left(\mathbf{g . k g}^{-1}\right)\end{array}$ & $\begin{array}{c}\text { Silt } \\
\left(\mathbf{g . k g} \mathbf{k g}^{-1}\right)\end{array}$ & $\begin{array}{c}\text { Clay } \\
\left(\mathbf{g . k g}^{-1}\right)\end{array}$ & $\begin{array}{c}\text { E.C. } \\
(\mathbf{d S . m}\end{array}$ & $\mathbf{p H}$ & $\begin{array}{c}\text { O.M. } \\
\left(\mathbf{g . k g}^{-1}\right)\end{array}$ & $\begin{array}{c}\mathbf{C a C O}_{\mathbf{3}} \\
\left(\mathbf{g . k g}^{-1}\right)\end{array}$ & $\begin{array}{c}\text { Total N } \\
\left(\mathbf{m g . k g}^{-1}\right)\end{array}$ & $\begin{array}{c}\mathbf{K}^{+} \\
\left(\mathbf{L}^{-1}\right)\end{array}$ \\
\hline Values & Clay & 41.0 & 430.50 & 528.50 & 0.61 & 7.32 & 21.6 & 107.0 & 1.07 & 0.12 \\
\hline
\end{tabular}

Note: E.C.: electronic conductivity; O.M.: organic matter; $\mathrm{CaCO}_{3}$ : Calcium Carbonate; $\mathrm{K}^{+}$: potassium ion

The measurements of agro-morphological traits for growth characteristics, yield, and its components were recorded. Measured traits were: 
- Plant Height: recorded at physiological maturity, height was recorded as the length in centimeters from the soil surface to the tip of spike excluding awns.

- Days to flowering: recorded as the number of days required from sowing till flower initiation.

- Days to maturity: recorded as the number of days required from sowing till physiological maturity.

- Spike number $/ \mathrm{m}^{2}$ : calculated as a number of spikes per unit area $\left(\mathrm{m}^{2}\right)$.

- Grains/spike: counted as an average of the number of grains per spike for 5 selected spikes randomly per each plot.

- 1000- Kernel weight (g): one thousand grain weight (g) were taken at random from a bulk grain yield of each replicate.

- Biomass yield (ton/ha): recorded as the weight of all biological products of the plant above the soil surface per unit area.

- Harvest index (HI): Counted as a percentage of grain weight to biomass, according to the following equation (Shewry, 1998).

$$
\text { H.I. }=\frac{\text { Grain yield }}{\text { biomass yield }}
$$

- Grain yield (ton/ha): calculated as a yield of grains of unit area, converted to ton per hectare.

Data were recorded for the agronomic traits, yield, and its components, and analyzed using XLSTAT 2016 software. The source of variance and comparison between the genotypes were determined. The comparisons of trait means were made using Duncan's multiple range test at $5 \%$ level of probability.

\section{Results and Discussion}

Studying phenological alteration such as vernalization is essential in winter wheat (Triticum aestivum L.), to cope with the adverse effects of global warming on crop production, especially under arid and semi-arid conditions (Shourbalal et al., 2019). It has been indicated that each degree increase in temperature results in the reduction of wheat production by 6\% (Asseng et al., 2015). Advancing the process of flowering, through partial phenological alteration in winter wheat, is an important step to reduce the effect of drought (Searle and Coupland, 2004). To induce yield production of winter wheat in mild and dried condition, a period of vernalization is required to initiate reproductive stage following vegetative growth (Heide and Sønsteby, 2015).

The analyzed results indicated a significant variance of the genotypes and their interaction treatments with variable incubation temperature and the exposure period to the incubated temperature (Table 4). Vernalization determines flowering and heading times, giving a significant influence on the adaptability of wheat plants to different environmental conditions, that mainly contribute to establishing yield and yield components (Slafer, 2003; Chen et al., 2013). Varieties had a highly significant variance for all the studied traits. The levels of incubation temperature had highly significant effects on days to maturity, spike number $/ \mathrm{m}^{2}$, grain number/spike, 1000 kernel weight, harvest index, and grain yield, while they had a significant effect on days to flowering. 
Table 4. Analysis of variance for agronomic traits, yield and its components of wheat varieties, incubation temperature and the period of incubation with their interaction effects

\begin{tabular}{|c|c|c|c|c|c|c|c|c|c|c|}
\hline \multirow[b]{2}{*}{ Source } & \multirow[b]{2}{*}{ df } & \multicolumn{9}{|c|}{ Mean square } \\
\hline & & $\begin{array}{c}\begin{array}{c}\text { Plant height } \\
(\mathrm{cm})\end{array} \\
\end{array}$ & $\begin{array}{c}\text { Days to } \\
\text { flowering }\end{array}$ & $\begin{array}{c}\text { Days to } \\
\text { maturity }\end{array}$ & $\begin{array}{c}\text { Spike } \\
\text { number/m² }\end{array}$ & $\begin{array}{c}\text { Grain } \\
\text { number/spike }\end{array}$ & $\begin{array}{c}1000 \text { kernel } \\
\text { weight }(\mathrm{g})\end{array}$ & $\begin{array}{c}\text { Harvest } \\
\text { index }\end{array}$ & $\begin{array}{c}\text { Biomass yield } \\
\text { (ton/ha) }\end{array}$ & $\begin{array}{c}\text { Grain yield } \\
\text { (ton/ha) }\end{array}$ \\
\hline Varieties $(\mathrm{F} 1)$ & 4 & $5293.328 * *$ & $3195.711^{* *}$ & $3678.933 * *$ & $31225.483 * *$ & $947.763 * *$ & $441.031 * *$ & $0.006^{* *}$ & $77.354 * *$ & $6.612 * *$ \\
\hline $\begin{array}{c}\text { Incubation } \\
\text { temperature (F2) }\end{array}$ & 2 & 5.204 & $7.878^{*}$ & $24.1 * *$ & $4107.011 * *$ & $128.795 * *$ & $19.313 * *$ & $0.018^{* *}$ & 0.644 & $3.133 * *$ \\
\hline $\begin{array}{c}\text { Period of } \\
\text { Incubation (F3) }\end{array}$ & 1 & $8.465^{*}$ & 0.178 & $33.611^{*}$ & 6.4 & 2.347 & 15.528 & 0.00037 & 1.686 & 0.015 \\
\hline Replicates & 2 & $15.481 * *$ & 1.078 & 1.9 & 49.244 & 4.065 & 1.801 & 0.001 & 1.126 & 0.037 \\
\hline Factor $1 *$ Factor 2 & 8 & $13.498 * *$ & $7.919 * *$ & $14.517 * *$ & $10485.858^{* *}$ & $107.45 * *$ & $16.118^{* *}$ & $0.002 * *$ & 0.965 & $0.707 * *$ \\
\hline Factor $1 *$ Factor 3 & 4 & $6.787 * *$ & 2.567 & $3.556^{*}$ & $1768.761 *$ & $20.051 *$ & $24.649 * *$ & $0.011^{* *}$ & $3.193^{* *}$ & $1.045^{* *}$ \\
\hline Factor2*Factor3 & 2 & 4.238 & $12.811^{* *}$ & $14.144 * *$ & 291.433 & 2.028 & $49.784 * *$ & $0.016^{* *}$ & $4.313^{* *}$ & $3.386^{* *}$ \\
\hline $\begin{array}{c}\text { Factor } 1 * \text { Factor } 2 * \\
\text { Factor } 3\end{array}$ & 8 & $6.103 * *$ & $20.992 * *$ & $10.172 * *$ & $3547.253 * *$ & $27.449 * *$ & $22.818 * *$ & $0.005^{* *}$ & $4.638 * *$ & $0.732 * *$ \\
\hline Error & 58 & 105.445 & 1.561 & 0.992 & 570.474 & 9.122 & 0.924 & 0.0003 & 0.614 & 0.015 \\
\hline Minimum & & 70.5 & 101 & 145 & 232 & 17.6 & 15.352 & 0.14 & 7.066 & 1.589 \\
\hline Maximum & & 117.5 & 143 & 182 & 484 & 55.75 & 33.992 & 0.341 & 16.813 & 4.968 \\
\hline Mean & & 84.378 & 125.644 & 170.367 & 350.822 & 32.989 & 23.568 & 0.248 & 12.52 & 3.18 \\
\hline Std. deviation & & 15.55 & 12.159 & 13.025 & 56.71 & 8.039 & 5.177 & 0.048 & 2.163 & 0.794 \\
\hline
\end{tabular}


Period of incubation for different temperatures had no significant effect on the studied traits, except plant height and days to maturity. The interaction of varieties $\times$ incubation temperature had a highly significant effect on all traits except for biomass yield. Distribution of the bio-product between sink and source for the wheat varieties was not influenced by the period of incubation. Both interactions of varieties $\times$ incubation temperature and varieties $\times$ incubation period had similar effects on the studied traits, as harvest index, biomass yield, plant height, and grain yield, and 1000 kernel weight were highly significant for both interactions. A very close pattern was also stated for the interaction between the incubation temperature and the incubation period. The interaction of all three factors showed a highly significant effect on all traits except grain number/spike.

Wheat varieties had a considerable variable effect on the studied characteristics (Table 5). Plant height tends to be the highest in Sabir-beg variety $(114.861 \mathrm{~cm})$, while other varieties have a close range of height with each other (only $4 \mathrm{~cm}$ differences), their values are ranging from $73.8-78,833 \mathrm{~cm}$ for Maribos and Ritraw, respectively. The local variety (Sabir-beg) spent shorter period to start flowering (101.94 days from sowing), it was earlier in flowering as well than Hereford with a total of 28 days. The same trend was obtained for days to maturity for Sabir-beg and Hereford, respectively. Maximum days required to maturity was referred to Mariboss, spending 179.7 days after sowing. Hereford had the highest number of spike per unit area $\left(413.667 \mathrm{spike} / \mathrm{m}^{2}\right)$, while the least number of spikes was referred to Mariboss.

Table 5. Effect of varieties on agronomic traits, yield and its components of wheat varieties

\begin{tabular}{|c|c|c|c|c|c|c|c|c|c|}
\hline 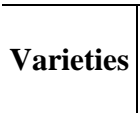 & $\begin{array}{c}\text { Plant } \\
\text { height (cn }\end{array}$ & Da & y & $\begin{array}{r}S_{\mathbf{I}} \\
\text { num }\end{array}$ & $\begin{array}{c}\text { Grain } \\
\text { number/ } \\
\text { spike }\end{array}$ & $\begin{array}{c}1000 \\
\text { kernel } \\
\text { weight }(g)\end{array}$ & t & $\begin{array}{c}\text { Biomass } \\
\text { yield } \\
\text { (ton } / \text { ha) }\end{array}$ & $\begin{array}{l}\text { Grain } \\
\text { yield } \\
\text { (ton } / \text { ha) }\end{array}$ \\
\hline & & & & & & & & & \\
\hline & & & & & & & & & $8 \mathrm{~d}$ \\
\hline Hers & b & $\mathrm{c}$ & $\mathrm{d}$ & 4 & 3 & & & $b$ & $3 \mathrm{~b}$ \\
\hline & & & & & 3 & & & $\mathrm{~b}$ & $2.733 \mathrm{~d}$ \\
\hline abirbeg & $114.861 \mathrm{a}$ & $101.944 \mathrm{~d}$ & $145.056 \mathrm{e}$ & $319.167 \mathrm{~d}$ & $22.633 \mathrm{e}$ & $31.298 \mathrm{a}$ & $0.204 \mathrm{a}$ & $15.756 \mathrm{a}$ & $4.162 \mathrm{a}$ \\
\hline
\end{tabular}

In terms of grain number/spike the highest number of 40.566 grain was recorded for Skalnige variety, followed by Ritraw, however the least number of grain (22.633) was recorded for Sabir-beg variety. A wide range of 1000 kernel weight was also observed for the varieties under study. The maximum of $31.298 \mathrm{~g}$ was recorded for Sabir-beg, while the lowest value of 1000 kernel weight was recorded for Hereford and Skalnige, respectively, with nearly $11 \mathrm{~g}$ less weight than Sabir-beg. Harvest Index was also significant for the varieties studied. Sabir-beg had the highest harvest index of 0.264, followed by Skalnige, while the lowest harvest index referred to Ritraw. Biomass was also indicated the variation between the varieties under study. Sabir-beg had indicated the highest biomass yield of 15.756 ton/ha, while the minimum of 10.069 ton/ha was recorded for Skalnige. The same pattern of superiority in the grain yield was recorded for Sabir-beg giving a total of 4.162 ton/ha grain yield. The superiority of local wheat varieties to most of the newly introduced genotypes in another study by Ali et al. (2018) compared to some European varieties for the yield and its component highly supports the current result. The genetic variations that drive a wide response of the genotype understudy could serve the development of a new cultivar with high resilience to future climate changes through the introgression of important traits. 
The levels of temperature treatment had variable effects on the studied traits (Table 6). Plant height had no significant difference for different temperature levels. Days to flowering was affected with $-18^{\circ} \mathrm{C}$ incubation, however the incubation at $4^{\circ} \mathrm{C}$ had no significant effect on flowering day. Vernalization sensitivity of some of the wheat varieties could be the reason for delaying flowering in certain environmental conditions (Ortiz-Ferrara et al., 1995), making the temperature level of $4^{\circ} \mathrm{C}$ to be with less effect to flowering compared to the normal ambient temperature of $22^{\circ} \mathrm{C}$. The same pattern was also observed for days to maturity, spending less days to maturity (166.333 days) for $18^{\circ} \mathrm{C}$ incubation. A positive effect of vernalization on days to flowering has been confirmed by other researchers (Sharma et al., 2012). This trend indicates the effect of low-temperature incubation on the vernalization of the varieties under study, giving the desired signal to vegetation period for some days, allowing plants to shift to flowering and maturity period earlier. Hence, in case of impossibility of sowing in the normal sowing times in autumn or at the beginning of winter, the requirement of vernalization could be afforded in vitro as a substitute to early sowing. In terms of the spike number per unit area, the low temperature of $4^{\circ} \mathrm{C}$ had a significant effect on the spike number (364.233 spike $\left./ \mathrm{m}^{2}\right)$.

Table 6. Effect of incubation temperature on agronomic traits, yield and its components of wheat varieties

\begin{tabular}{c|c|c|c|c|c|c|c|c|c}
\hline Temperature & $\begin{array}{c}\text { Plant } \\
\text { height }\end{array}$ & $\begin{array}{c}\text { Days to } \\
\text { flowering }\end{array}$ & $\begin{array}{c}\text { Days to } \\
\text { maturity }\end{array}$ & $\begin{array}{c}\text { Spike } \\
\text { number/m }\end{array}$ & $\begin{array}{c}\text { Grain } \\
\text { number/ } \\
\text { spike }\end{array}$ & $\begin{array}{c}\mathbf{1 0 0 0} \\
\text { kernel } \\
\text { weight }(\mathbf{g})\end{array}$ & $\begin{array}{c}\text { Harvest } \\
\text { index }\end{array}$ & $\begin{array}{c}\text { Biomass } \\
\text { yield } \\
\text { (ton/ha) }\end{array}$ & $\begin{array}{c}\text { Grain } \\
\text { yield } \\
\text { (ton/ha) }\end{array}$ \\
\hline $\mathbf{2 2}{ }^{\circ} \mathbf{C}$ & $84.266 \mathrm{a}$ & $125.300 \mathrm{a}$ & $170.833 \mathrm{a}$ & $345.533 \mathrm{~b}$ & $35.297 \mathrm{a}$ & $23.701 \mathrm{~b}$ & $0.268 \mathrm{a}$ & $12.669 \mathrm{a}$ & $3.475 \mathrm{a}$ \\
$\mathbf{4}^{\circ} \mathbf{C}$ & $84.839 \mathrm{a}$ & $125.400 \mathrm{a}$ & $170.933 \mathrm{a}$ & $364.233 \mathrm{a}$ & $32.383 \mathrm{~b}$ & $22.707 \mathrm{c}$ & $0.256 \mathrm{~b}$ & $12.376 \mathrm{a}$ & $3.232 \mathrm{~b}$ \\
$\mathbf{- 1 8}{ }^{\circ} \mathbf{C}$ & $84.029 \mathrm{a}$ & $122.233 \mathrm{~b}$ & $166.333 \mathrm{~b}$ & $342.700 \mathrm{~b}$ & $31.288 \mathrm{~b}$ & $24.295 \mathrm{a}$ & $0.221 \mathrm{c}$ & $12.514 \mathrm{a}$ & $2.835 \mathrm{c}$ \\
\hline
\end{tabular}

A reverse effect was recorded for the vernalization temperatures on the number of grains per spike, as the increased chilling temperature has negatively reduced the grain number/spike. There were also significant differences in the levels of incubation temperature for 1000 kernel weight. Decreasing the temperature to $4^{\circ} \mathrm{C}$ had a negative effect on the weight of kernels, while a further reduction in the incubation temperature to $-18^{\circ} \mathrm{C}$ had increased the weight of 1000 kernels (24.295 g). Harvest index was negatively affected due to the reduced temperature. Total biomass was not affected by different incubation levels. The accumulation of bio-product is more genetically controlled (Kumar et al., 2016; Brinton et al., 2017), while tracking the product to be accumulated to different parts of the plant is a matter of environmental effect in addition to genetic structure. Grain yield was identified to be reduced by decreasing the incubation temperature.

The incubation period for the wheat varieties seems to have a high effect on plant height and days to maturity (Table 7). Plant height had a few increases with the extended incubation period, while days to maturity has decreased with the same trends of incubation extension. No significant increase in grain weight was realized by increasing the period of incubation from two to four weeks duration. This result indicates the satisfaction period of two weeks incubation at low temperature for the wheat varieties under study. The varieties under study might be weak winter genotypes and the 2 weeks duration could be satisfactory for vernalization as extending to four weeks duration of a cold explosion being non-necessary for the current genotypes. 
Table 7. Effect of incubation period on agronomic traits, yield and its components of wheat varieties

\begin{tabular}{c|c|c|c|c|c|c|c|c|c}
\hline $\begin{array}{c}\text { Period of } \\
\text { incubation }\end{array}$ & $\begin{array}{c}\text { Plant } \\
\text { height } \\
\text { (cm) }\end{array}$ & $\begin{array}{c}\text { Days to } \\
\text { flowering }\end{array}$ & $\begin{array}{c}\text { Days to } \\
\text { maturity }\end{array}$ & $\begin{array}{c}\text { Spike } \\
\text { number/m2 }\end{array}$ & $\begin{array}{c}\text { Grain } \\
\text { number/ } \\
\text { spike }\end{array}$ & $\begin{array}{c}\text { 1000 } \\
\text { kernel } \\
\text { weight } \text { (g) })\end{array}$ & $\begin{array}{c}\text { Harvest } \\
\text { index }\end{array}$ & $\begin{array}{c}\text { Biomass } \\
\text { yield } \\
\text { (ton/ha) }\end{array}$ & $\begin{array}{c}\text { Grain } \\
\text { yield } \\
\text { (ton/ha) }\end{array}$ \\
\hline Two weeks & $84.071 \mathrm{~b}$ & $169.756 \mathrm{a}$ & $13.383 \mathrm{a}$ & $351.089 \mathrm{a}$ & $33.151 \mathrm{a}$ & $23.153 \mathrm{a}$ & $0.250 \mathrm{a}$ & $12.383 \mathrm{a}$ & $3.193 \mathrm{a}$ \\
Four weeks & $84.984 \mathrm{a}$ & $170.978 \mathrm{a}$ & $11.657 \mathrm{~b}$ & $350.556 \mathrm{a}$ & $32.828 \mathrm{a}$ & $23.983 \mathrm{a}$ & $0.247 \mathrm{a}$ & $12.657 \mathrm{a}$ & $3.167 \mathrm{a}$ \\
\hline
\end{tabular}

The interaction of varieties $\times$ incubation temperature for the grain of wheat varieties had different effects on the studied characteristics (Table 8). The interaction between Sabir-beg and $4^{\circ} \mathrm{C}$ gave the maximum plant height of $115.583 \mathrm{~cm}$, while the minimum plant height of $72.078 \mathrm{~cm}$ was referred to as the interaction between Mariboss and $22^{\circ} \mathrm{C}$ incubation. Same interaction effect of Sabir-beg $\times 4^{\circ} \mathrm{C}$ was recorded for minimum days required to flowering (101.667 days). The interaction of Sabir-beg variety to other incubation temperatures had the same effect on the days to flowering. The maximum number of days required to start flowering (131.5 days) was recorded for the interaction between Mariboss and $22^{\circ} \mathrm{C}$ incubation. Like days to flowering the minimum days to maturity was referred to Sabir-beg interaction with different incubation temperatures, requiring 145 days to maturity, however, the maximum days spent to maturity was recorded for Mariboss with the incubation of $22^{\circ} \mathrm{C} \times 4^{\circ} \mathrm{C}$. The maximum spike number of $442 \mathrm{spike} / \mathrm{m}^{2}$ was identified for the interaction of Hereford $\times 22^{\circ} \mathrm{C}$ incubation, followed by the interaction of the same variety with $-18^{\circ} \mathrm{C}$. The minimum number of spikes $/ \mathrm{m}^{2}$ was recorded for Mariboss interacted with $22^{\circ} \mathrm{C}$ incubation. Grain number is one of the yield component traits that was recorded as a maximum of 49.667 grains/spike for the interaction of Skalnige variety with $22^{\circ} \mathrm{C}$ incubation.

Table 8. Interaction effect of varieties $\times$ incubation temperature on agronomic traits, yield and its components of wheat varieties

\begin{tabular}{|c|c|c|c|c|c|c|c|c|c|}
\hline $\begin{array}{c}\text { Varieties } \times \\
\text { incubation } \\
\text { temperature }\end{array}$ & $\begin{array}{l}\text { Plant } \\
\text { Height } \\
(\mathbf{c m})\end{array}$ & $\begin{array}{c}\text { Days to } \\
\text { flowering }\end{array}$ & $\begin{array}{c}\text { Days to } \\
\text { maturity }\end{array}$ & $\begin{array}{c}\text { Spike } \\
\text { number/m} / \mathbf{m}^{2}\end{array}$ & $\begin{array}{c}\text { Grain } \\
\text { number/ } \\
\text { spike }\end{array}$ & $\begin{array}{c}1000 \\
\text { kernel } \\
\text { weight }(g)\end{array}$ & $\begin{array}{c}\text { Harvest } \\
\text { index }\end{array}$ & $\begin{array}{c}\text { Biomass } \\
\text { yield } \\
\text { (ton/ha) }\end{array}$ & $\begin{array}{c}\text { Grain } \\
\text { yield } \\
\text { (ton/ha) }\end{array}$ \\
\hline $2^{\circ} \mathrm{C}$ & $72.078 \mathrm{~h}$ & de & & & 26 & 22 & & $6 \mathrm{a}$ & $38 \mathrm{fg}$ \\
\hline Mar & $73.155 \mathrm{gh}$ & $133.833 \mathrm{~b}$ & $180.667 \mathrm{a}$ & 347.667 efg & $30.217 \mathrm{e}$ & $22.484 \mathrm{f}$ & $0.280 \mathrm{abc}$ & $11.393 \mathrm{a}$ & $140 \mathrm{e}$ \\
\hline $\begin{array}{c}\text { Mariboss } \times \\
-18^{\circ} \mathrm{C}\end{array}$ & $76.189 \mathrm{f}$ & $136.167 \mathrm{a}$ & $177.667 \mathrm{~b}$ & $331.000 \mathrm{fgh}$ & $30.333 \mathrm{e}$ & $23.747 \mathrm{e}$ & $0.229 \mathrm{~g}$ & $11.824 \mathrm{a}$ & $2.737 \mathrm{~g}$ \\
\hline Skalnige $\times 22^{\circ} \mathrm{C}$ & $76.833 \mathrm{ef}$ & 130. & $179.667 \mathrm{a}$ & 35 & $49.667 \mathrm{a}$ & $19.869 \mathrm{~h}$ & 0.2 & $3 a$ & $58 \mathrm{fg}$ \\
\hline & 77.98 & 130 & $177.667 \mathrm{~b}$ & 316 & 37.8 & $17.133 \mathrm{j}$ & & $67 \mathrm{a}$ & $58 \mathrm{~h}$ \\
\hline $\begin{array}{r}\text { Skalr } \\
-18\end{array}$ & $9 \mathrm{~g}$ & $\mathrm{~cd}$ & $7 \mathrm{~cd}$ & fgh & $\mathrm{cd}$ & $8 \mathrm{~g}$ & lef & 10. & $2.900 \mathrm{f}$ \\
\hline Hereford $\times 22^{\circ} \mathrm{C}$ & $78.083 \mathrm{cde}$ & $3 \mathrm{def}$ & $174.000 \mathrm{~cd}$ & $442.000 \mathrm{a}$ & $3.233 \mathrm{de}$ & $18.696 \mathrm{i}$ & $0.284 \mathrm{ab}$ & $2.300 \mathrm{a}$ & $3.818 \mathrm{c}$ \\
\hline & $78.883 \mathrm{c}$ & 130. & $173.667 \mathrm{~d}$ & $380.333 \mathrm{~cd}$ & $37.033 \mathrm{~cd}$ & $19.919 \mathrm{~h}$ & $0.252 \mathrm{defg}$ & $12.427 \mathrm{a}$ & $3.505 \mathrm{~d}$ \\
\hline $\begin{array}{r}\text { Her } \\
-1\end{array}$ & $77.083 \mathrm{def}$ & & 1 & 4 & 3 & 1 & b & $7 \mathrm{a}$ & $7 \mathrm{fg}$ \\
\hline Ritraw $\times 22^{\circ} \mathrm{C}$ & $7 \mathrm{c}$ & $0 \mathrm{c}$ & $174.667 \mathrm{~cd}$ & 381.6 & $42.633 \mathrm{~b}$ & 27. & efg & $8 \mathrm{a}$ & $3.169 \mathrm{e}$ \\
\hline & 78.5 & 131.3 & $177.500 \mathrm{~b}$ & 406.6 & $35.917 \mathrm{~cd}$ & $16 \mathrm{f}$ & $4 \mathrm{fg}$ & $12.362 \mathrm{a}$ & $2.895 \mathrm{fg}$ \\
\hline Ritra & $78.750 \mathrm{~cd}$ & $131.500 \mathrm{cdef}$ & $175.000 \mathrm{c}$ & 320.333 ghi & $36.217 \mathrm{~cd}$ & $26.015 \mathrm{~g}$ & $0.180 \mathrm{i}$ & $11.866 \mathrm{a}$ & $2.134 \mathrm{i}$ \\
\hline $\begin{array}{c}\text { Sabir- } \\
\text { beg } \times 22^{\circ} \mathrm{C}\end{array}$ & 115 & 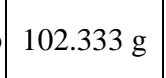 & 1 & 288 & 24. & 30 & $0 ?$ & 16. & 4.7 \\
\hline Sabir-beg $\times 4^{\circ} \mathrm{C}$ & $115.583 \mathrm{a}$ & 101.0 & 145. & 369 & 20.5 & 32.1 & 0.26 & $15.633 \mathrm{a}$ & 4.0 \\
\hline $\begin{array}{c}\text { Sabir- } \\
\text { beg } \times-18^{\circ} \mathrm{C}\end{array}$ & 113.8 & 101.8 & 145.0 & 299.8 & $22.433 \mathrm{~g}$ & $31.233 \mathrm{ab}$ & $0.233 \mathrm{fg}$ & $15.565 \mathrm{a}$ & $3.634 \mathrm{~d}$ \\
\hline
\end{tabular}


The minimum grain number/spike referred to the interaction of Sabir-beg with all incubation treatments. From this result, it seems that the grain number trait is mainly genotype-related (Guo et al., 2015), as the incubation treatment has no significant effect on the improvement of this trait. The interaction of Sabir-beg with the $4^{\circ} \mathrm{C}$ and $-18^{\circ} \mathrm{C}$ incubations showed the maximum weight of 1000 kernel $(32.185 \mathrm{~g}$ and $31.233 \mathrm{~g}$, respectively). Skalnige interacting with $4^{\circ} \mathrm{C}$ incubation had the minimum of 1000 kernel weight $(17.1333 \mathrm{~g})$. The interaction of Sabir-beg with the $4^{\circ} \mathrm{C}$ had the maximum record for harvest index, biomass yield and grain yield, while the minimum record refer to Ritraw interacting with $-18^{\circ} \mathrm{C}$ incubation for both traits of harvest index and grain yield. It is clear that Sabir-beg is the most adapted variety to the local environment, requiring less vernalization, which makes the interaction of this variety with low incubation temperatures to give less effect. In terms of biomass yield the minim value (however not significant) referred to the interaction of Skalnige with all incubation temperatures. Less vernalization effect on the European varieties characteristics in this study could refer to the presence of allelic variation (VRN) at vernalization (Whittal et al., 2018). Presence of another allele (VRN4) or recessive VRN allele to VRNI gene could drive the transcription of this gene without severe needs for vernalization period (Goncharov, 2004; Kippes et al., 2015), or they might be semi-winter cultivars that require less period of low incubation temperature for full vernalization, and capable of switching to generative development under local environmental conditions (Goncharov, 2004; Li et al., 2013). Another possibility is that, planting the current varieties by mid of December did not allow the germinated plant to catch enough short day exposure, as a short day phototropism combined with low temperatures is required to permit VRN1 expression for floral transition of the meristem at an earlier period (Hemming et al., 2008; Li and Dubcovsky, 2008; Whittal et al., 2018), as a result no realized differences between the treated vernalization and controlled wheat grains were recorded.

The interaction between varieties and incubation periods had different effects on the studied characteristics (Table 9). Plant height had the maximum value of $115.722 \mathrm{~cm}$ for the interaction between Sabir-beg and four weeks incubation, followed by the interaction Sabir-beg $\times$ two weeks incubations. A minimum plant height was referred to as Mariboss interacted with four weeks incubations. The same interaction of Sabir-beg $\times 2$ weeks incubation had spent the minimum days to start flowering (101.778). Regarding plant height, the maximum days required to start flowering was recorded for Mariboss interacting with two and four weeks incubations. The same pattern was also realized for days to maturity. Spike number was identified to be at the maximum rate $(423.00$ spike $/ \mathrm{m}^{2}$ ) for Hereford interacting with two weeks incubation, while the least value was recorded for the interaction of Mariboss $\times 2$ weeks incubation, giving 296.444 spike $/ \mathrm{m}^{2}$.

A maximum number of 40.978 and 40.133 grain/spike was identified for Skalnige interacting with two and four weeks incubations, while the least number of 22.39 grains/spike referred to Sabir-beg interacting with two weeks interaction. The highest 1000 kernel weight was $31.488 \mathrm{~g}$ and $31.109 \mathrm{~g}$ for Sabir-beg interacting with two and four weeks incubations, respectively. While the interaction of Hereford with four weeks incubation had the lowest weight of $18.506 \mathrm{~g}$ for 1000 grain of wheat. Harvest index was identified to be at a maximum rate of 0.289 for Mariboss interacting with four weeks of incubation. Biomass yield had the maximum value of 15.773 and 15.739 ton/ha for Sabir-beg variety interacting with two and four weeks of incubation, respectively. A minimum value of 9.231 ton/ha was recorded for Skalnige interacting with two weeks incubation. Grain yield also had the same pattern as biomass yield, giving the maximum 
yield of 4.197 and 4.127 ton/ha for the interaction of Sabir-beg with two and four weeks of incubation, respectively. The minimum grain yield was recorded for Mariboss interacting with 2 weeks incubation. The results here indicated the superiority of Sabirbeg interacting with both incubation periods, which surpassed other varieties in the majority of traits. The persistence of the genotypes is a major insight for this experiment, as the incubation of four weeks period had no significant change compared to the two weeks incubation.

Table 9. Effect of varieties and period of storage interaction on agronomic traits, yield and its components of wheat varieties

\begin{tabular}{|c|c|c|c|c|c|c|c|c|c|}
\hline $\begin{array}{c}\text { Varieties } \times \\
\text { Incubation period }\end{array}$ & $\begin{array}{c}\text { Plant } \\
\text { height } \\
(\mathbf{c m})\end{array}$ & $\begin{array}{c}\text { Days to } \\
\text { flowering }\end{array}$ & $\begin{array}{l}\text { Days to } \\
\text { maturity }\end{array}$ & $\begin{array}{c}\text { Spike } \\
\text { number/m} / \mathbf{m}^{2}\end{array}$ & $\begin{array}{c}\text { Grain } \\
\text { number/ } \\
\text { spike }\end{array}$ & $\begin{array}{c}1000 \\
\text { kernel } \\
\text { weight (g) }\end{array}$ & $\begin{array}{c}\text { Harvest } \\
\text { index }\end{array}$ & $\begin{array}{c}\text { Biomass } \\
\text { yield } \\
\text { (ton/ha) }\end{array}$ & $\begin{array}{c}\text { Grain } \\
\text { yield } \\
\text { (ton/ha) } \\
\end{array}$ \\
\hline $\begin{array}{l}\text { Mariboss } \times 2 \text { weeks } \\
\text { incubation }\end{array}$ & $74.352 \mathrm{f}$ & $133.333 \mathrm{a}$ & $178.889 \mathrm{~b}$ & $296.444 \mathrm{f}$ & $30.867 \mathrm{e}$ & $20.521 d$ & $0.210 \mathrm{e}$ & $11.954 \mathrm{~cd}$ & $2.522 \mathrm{f}$ \\
\hline $\begin{array}{l}\text { Mariboss } \times 4 \text { weeks } \\
\text { incubation }\end{array}$ & $73.263 \mathrm{f}$ & 134. & $180.556 \mathrm{a}$ & $327.333 \mathrm{de}$ & $27.100 \mathrm{f}$ & $25.123 b c$ & $0.289 \mathrm{a}$ & $11.449 \mathrm{de}$ & $3.289 \mathrm{c}$ \\
\hline $\begin{array}{l}\text { Skalnige } \times 2 \text { weeks } \\
\text { incubation }\end{array}$ & 75.859 e & $131.222 \mathrm{a}$ & $176.111 \mathrm{c}$ & $347.000 \mathrm{~cd}$ & $40.978 \mathrm{a}$ & 19.076 ef & $0.281 \mathrm{ab}$ & $9.231 \mathrm{f}$ & $2.838 \mathrm{e}$ \\
\hline $\begin{array}{r}\text { Skalnig } \\
\text { ince }\end{array}$ & $76.881 \mathrm{de}$ & $130.333 \mathrm{a}$ & $178.222 \mathrm{~b}$ & $332.667 \mathrm{de}$ & $40.133 a b$ & $19.664 \mathrm{de}$ & $0.242 \mathrm{~d}$ & $10.906 \mathrm{e}$ & $2.638 \mathrm{f}$ \\
\hline $\begin{array}{r}\text { Heref } \\
\text { in }\end{array}$ & $77.200 \mathrm{~d}$ & $130.333 \mathrm{a}$ & $173.778 \mathrm{e}$ & $423.000 \mathrm{a}$ & $33.815 \mathrm{~d}$ & $20.154 \mathrm{~d}$ & $0.264 b c$ & $12.496 \mathrm{bc}$ & $3.578 \mathrm{~b}$ \\
\hline $\begin{array}{l}\text { Herefo } \\
\text { inc }\end{array}$ & $78.833 \mathrm{c}$ & $129.778 \mathrm{a}$ & 174 & $3 \mathrm{a}$ & $35.222 \mathrm{~cd}$ & $18.506 \mathrm{f}$ & $0.232 \mathrm{~d}$ & $12.859 \mathrm{~b}$ & $3.149 \mathrm{~d}$ \\
\hline $\begin{array}{r}\text { Ritra } \\
\text { in }\end{array}$ & $78.944 \mathrm{c}$ & $131.778 \mathrm{a}$ & $174.889 \mathrm{~d}$ & $372.556 \mathrm{~b}$ & $37.700 \mathrm{bc}$ & $24.524 \mathrm{c}$ & $0.232 \mathrm{~d}$ & $12.460 \mathrm{bc}$ & $2.902 \mathrm{e}$ \\
\hline $\begin{array}{r}\text { Ritraw } \\
\text { incu }\end{array}$ & $78.722 \mathrm{c}$ & $131.444 \mathrm{a}$ & $176.556 \mathrm{c}$ & $366.556 \mathrm{bc}$ & $38.811 \mathrm{ab}$ & $25.514 b$ & $0.207 \mathrm{e}$ & $12.330 \mathrm{bc}$ & $2.563 \mathrm{f}$ \\
\hline $\begin{array}{c}\text { Sabir-beg } \times 2 \text { weeks } \\
\text { incubation }\end{array}$ & $114.000 \mathrm{~b}$ & $101.778 \mathrm{a}$ & $145.111 \mathrm{f}$ & 316.444 ef & $22.394 \mathrm{~g}$ & $31.488 \mathrm{a}$ & $0.261 \mathrm{c}$ & $15.773 \mathrm{a}$ & $4.127 \mathrm{a}$ \\
\hline $\begin{array}{l}\text { Sabir-beg } \times 4 \text { weeks } \\
\text { incubation }\end{array}$ & $115.722 \mathrm{a}$ & $102.111 \mathrm{a}$ & $145.000 \mathrm{f}$ & $321.889 \mathrm{e}$ & $22.872 \mathrm{~g}$ & $31.109 \mathrm{a}$ & $0.266 b c$ & $15.739 \mathrm{a}$ & $4.198 \mathrm{a}$ \\
\hline
\end{tabular}

The effect of different vernalization temperatures and the period of incubation is clarified in Table 10. The interaction between incubation temperature and the period of incubation was not significant however the highest plant height of $85.44 \mathrm{~cm}$ was recorded for $4^{\circ} \mathrm{C} \times 4$ weeks incubation. The same interaction was significant for days to flowering, recording the least days spent to flowering, while it had the highest and most significant number of days to maturity. It seems from this result that the interaction effect of $4^{\circ} \mathrm{C}$ incubation with four weeks period had allowed the flowering to be advanced, allowing the plant to stay longer in the flowering stage giving a higher number of spike per unit area with reasonable biomass. Proper management of the flowering period results in higher productivity, however, the highest yield of 3.584 has resulted from the interaction of $4^{\circ} \mathrm{C} \times 2$ weeks incubation. Significant effect of vernalization in wheat has been investigated previously at the temperature below $10^{\circ} \mathrm{C}$ (Robertson et al., 1996).

Same interaction of $4^{\circ} \mathrm{C} \times 4$ weeks incubation showed the highest potential of 365.333 spikes per square meter, however it is not statistically significant. Grain number/spike was also not significant for the interaction between the incubation temperature and the period of incubation, while the maximum value of 35.43 grain/spike was recorded for the interaction between $22^{\circ} \mathrm{C} \times 2$ weeks incubation. The interaction 
of $-18^{\circ} \mathrm{C} \times 4$ weeks incubation showed the highest value of $26.182 \mathrm{~g}$ for 1000 kernel weight. The interaction of $4^{\circ} \mathrm{C} \times 2$ weeks incubation gave the highest harvest index of 0.281 , while the lowest value referred to the interaction of $-18^{\circ} \mathrm{C} \times 2$ weeks incubation. Biomass yield recorded the maximum value of 13.007 followed by 12.931 ton/ha for the interaction of $-18^{\circ} \mathrm{C} \times 4$ weeks incubation and $22^{\circ} \mathrm{C} \times 2$ weeks incubation, respectively. Grain yield was identified to reach a maximum of 3.584 ton/ha for the interaction of $4^{\circ} \mathrm{C} \times 2$ weeks incubation, the lowest grain yield of 2.515 ton/ha has been identified for the interaction between $-18^{\circ} \mathrm{C}$ and 2 weeks incubation. This combination treatment between different incubation temperatures and their periods could explore the efficiency of $4^{\circ} \mathrm{C}$ with two weeks incubation could be satisfactory to induce the vernalization in the wheat varieties under study, as any further extension in the duration of cold treatment would not affect a reduction in the flowering period (Kim et al., 2009).

Table 10. Effect of temperature and period of storage interaction on vegetative growth, yield and its components of wheat varieties

\begin{tabular}{|c|c|c|c|c|c|c|c|c|c|}
\hline $\begin{array}{c}\text { Temperature } \times \\
\text { incubation period }\end{array}$ & $\begin{array}{c}\text { Plant } \\
\text { Height } \\
(\mathbf{c m})\end{array}$ & $\begin{array}{c}\text { Days to } \\
\text { Flowering }\end{array}$ & $\begin{array}{l}\text { Days to } \\
\text { maturity }\end{array}$ & $\begin{array}{c}\text { Spike } \\
\text { number/m² }\end{array}$ & $\begin{array}{c}\text { Grain } \\
\text { number/ } \\
\text { Spike }\end{array}$ & $\begin{array}{c}1000 \\
\text { kernel } \\
\text { weight }\end{array}$ & $\begin{array}{c}\text { Harvest } \\
\text { index }\end{array}$ & $\begin{array}{c}\text { Biomass } \\
\text { yield }\end{array}$ & $\begin{array}{l}\text { Grain } \\
\text { yield }\end{array}$ \\
\hline $\begin{array}{l}22^{\circ} \mathrm{C} \times 2 \text { weeks } \\
\text { incubation }\end{array}$ & $84.382 \mathrm{a}$ & $125.267 \mathrm{bc}$ & $170.867 \mathrm{~b}$ & $343.600 \mathrm{a}$ & $35.430 \mathrm{a}$ & $23.834 \mathrm{~b}$ & $0.267 \mathrm{a}$ & $12.931 \mathrm{a}$ & $3.481 \mathrm{~b}$ \\
\hline $\begin{array}{l}22^{\circ} \mathrm{C} \times 4 \text { weeks } \\
\text { incubation }\end{array}$ & $84.149 \mathrm{a}$ & $125.333 b c$ & $170.800 \mathrm{~b}$ & $347.467 \mathrm{a}$ & $35.163 \mathrm{a}$ & $23.568 \mathrm{~b}$ & $0.268 \mathrm{a}$ & $12.408 \mathrm{ab}$ & $3.468 \mathrm{~b}$ \\
\hline $\begin{array}{l}4^{\circ} \mathrm{C} \times 2 \text { weeks } \\
\text { incubation }\end{array}$ & $84.238 \mathrm{a}$ & $126.133 \mathrm{ab}$ & $169.600 \mathrm{c}$ & $363.133 \mathrm{a}$ & $32.300 \mathrm{a}$ & $23.215 b$ & $0.281 \mathrm{a}$ & $12.197 \mathrm{~b}$ & $3.584 \mathrm{a}$ \\
\hline $\begin{array}{l}4^{\circ} \mathrm{C} \times 4 \text { weeks } \\
\text { incubation }\end{array}$ & $85.440 \mathrm{a}$ & $124.667 \mathrm{c}$ & $172.267 \mathrm{a}$ & $365.333 \mathrm{a}$ & $32.467 \mathrm{a}$ & $22.200 \mathrm{c}$ & $0.232 \mathrm{~b}$ & $12.556 \mathrm{ab}$ & $2.880 \mathrm{~d}$ \\
\hline $\begin{array}{l}-18^{\circ} \mathrm{C} \times 2 \text { weeks } \\
\text { incubation }\end{array}$ & $83.593 \mathrm{a}$ & $125.667 \mathrm{~b}$ & $168.800 \mathrm{~d}$ & $346.533 \mathrm{a}$ & $31.722 \mathrm{a}$ & $22.408 \mathrm{c}$ & $0.201 \mathrm{c}$ & $12.021 \mathrm{~b}$ & $2.515 \mathrm{e}$ \\
\hline $\begin{array}{l}-18^{\circ} \mathrm{C} \times 4 \text { weeks } \\
\text { incubation }\end{array}$ & $84.464 \mathrm{a}$ & $126.800 \mathrm{a}$ & $169.867 \mathrm{c}$ & $338.867 \mathrm{a}$ & $30.853 \mathrm{a}$ & $26.182 \mathrm{a}$ & $0.242 \mathrm{~b}$ & $13.007 \mathrm{a}$ & $3.154 \mathrm{c}$ \\
\hline
\end{tabular}

There are variable effects on all the traits with the triple interaction effect of varieties $\times$ temperature $\times$ incubation period (Table 11). Sabir-beg interacting with the other two factors showed the best records for the traits plant height, days to flowering, days to maturity, 1000 kernel weight, biomass and grain yield. The reason for surpassing Sabir-beg by the other genotypes either individually or interacting with other factors could refer to the genetic architecture of these genotypes to validate VRN1 alleles to reduce or eliminating the vernalization requirement and able to manage the vernalization stage in a few days at a suitable temperature ranged from $5-20^{\circ} \mathrm{C}$ (Mureşan et al., 2019). Hereford $\times 4^{\circ} \mathrm{C} \times$ two weeks incubation had a reasonable grain yield after Sabir-beg, recoding 4.546 ton/ha, also the maximum harvest index of 0.327 was recorded for it.

Despite the above results for the interaction of genotypes, incubation temperature, and its period, many other genotypic and environmental factors could be involved in this highly complex biological process. It is identified that mechanisms of vernalization are not just genetically controlled, they are also categorized based on their interactions with the environment (Griffiths et al., 2009). Despite the complexity of genetic and environmental interaction in vernalization operation, other genes are also involved in relation to vernalization, such as VER2 (Yong et al., 2003), which encourage devernalization in wheat by silencing the activity of VRN1 gene. 
Table 11. Effect of the interaction between varieties, temperature and period of storage on vegetative growth, yield and its components of wheat varieties

\begin{tabular}{|c|c|c|c|c|c|c|c|c|c|}
\hline $\begin{array}{c}\text { Varieties } \times \text { Temperature } \\
\text { incubation }\end{array}$ & $\begin{array}{l}\text { Plant } \\
\text { height }\end{array}$ & $\begin{array}{l}\text { Days to } \\
\text { flowering }\end{array}$ & $\begin{array}{l}\text { Days to } \\
\text { maturity }\end{array}$ & $\begin{array}{c}\text { Spike } \\
\text { number/unit area }\end{array}$ & $\begin{array}{c}\text { Grain number/ } \\
\text { Spike }\end{array}$ & $\begin{array}{c}1000 \text { kernel } \\
\text { weight }\end{array}$ & $\begin{array}{c}\text { Harvest } \\
\text { index }\end{array}$ & Biomass yield & $\begin{array}{l}\text { Grain } \\
\text { yield }\end{array}$ \\
\hline Mariboss $\times 22^{\circ} \mathrm{C} \times$ Two weeks & $72.578 \mathrm{jk}$ & $131.333 \mathrm{cde}$ & $181.000 \mathrm{a}$ & $252.000 \mathrm{k}$ & $26.400 \mathrm{ijk}$ & 22.402 ef & $0.237 \mathrm{ijkl}$ & $12.053 \mathrm{efgh}$ & $2.855 \mathrm{jkl}$ \\
\hline Mariboss $\times 22^{\circ} \mathrm{C} \times$ Four weeks & $71.578 \mathrm{k}$ & $131.667 \mathrm{~cd}$ & $180.667 \mathrm{a}$ & $262.000 \mathrm{k}$ & $26.400 \mathrm{ijk}$ & 22.069 efg & 0.243 hijkl & 11.720 efghi & $2.821 \mathrm{jkl}$ \\
\hline Mariboss $\times 4^{\circ} \mathrm{C} \times$ Two weeks & $72.589 \mathrm{jk}$ & $137.000 \mathrm{~b}$ & $180.333 \mathrm{a}$ & 341.333 fghi & $30.533 \mathrm{hi}$ & $21.593 \mathrm{fgh}$ & 0.243 hijkl & 12.369 cdefg & $2.999 \mathrm{ijk}$ \\
\hline Mariboss $\times 4^{\circ} \mathrm{C} \times$ Four weeks & $73.722 \mathrm{ijk}$ & $130.667 \mathrm{de}$ & $181.000 \mathrm{a}$ & 354.000 defgh & 29.900 hij & $23.374 \mathrm{de}$ & $0.317 \mathrm{ab}$ & $10.417 \mathrm{ijk}$ & $3.282 \mathrm{gh}$ \\
\hline Mariboss $\times-18{ }^{\circ} \mathrm{C} \times$ Two weeks & $77.888 \mathrm{cde}$ & $131.667 \mathrm{~cd}$ & $175.333 \mathrm{~b}$ & $296.000 \mathrm{Jk}$ & 35.667 efgh & $17.568 \mathrm{~lm}$ & $0.151 \mathrm{o}$ & 11.440 fghij & $1.712 \mathrm{o}$ \\
\hline Mariboss $\times-18^{\circ} \mathrm{C} \times$ Four weeks & 74.489 hij & $140.667 \mathrm{a}$ & $180.000 \mathrm{a}$ & 366.000 defgh & $25.000 \mathrm{jkl}$ & $29.925 \mathrm{~b}$ & $0.308 \mathrm{abc}$ & $12.209 \mathrm{efgh}$ & $3.763 \mathrm{e}$ \\
\hline Skalnige $\times 22^{\circ} \mathrm{C} \times$ Two weeks & 77.000 defg & $130.333 \mathrm{de}$ & $180.000 \mathrm{a}$ & 374.000 defg & $52.000 \mathrm{a}$ & $19.869 \mathrm{hijk}$ & 0.272 defghi & $10.133 \mathrm{jk}$ & 2.7581 \\
\hline Skalnige $\times 22^{\circ} \mathrm{C} \times$ Four weeks & 76.667 efgh & $130.333 \mathrm{de}$ & $179.333 \mathrm{a}$ & 344.000 efghi & $47.333 \mathrm{ab}$ & 19.869 hijk & 0.272 defghi & $10.133 \mathrm{jk}$ & 2.7581 \\
\hline Skalnige $\times 4^{\circ} \mathrm{C} \times$ Two weeks & 77.333 cdefg & $130.000 \mathrm{de}$ & $174.333 \mathrm{bc}$ & $340.333 \mathrm{ghi}$ & 37.133 defg & $16.405 \mathrm{~m}$ & 0.293 abcdef & $9.373 \mathrm{kl}$ & 2.7391 \\
\hline Skalnige $\times 4^{\circ} \mathrm{C} \times$ Four weeks & 78.644 cde & $130.333 \mathrm{de}$ & $181.000 \mathrm{a}$ & $293.333 \mathrm{jk}$ & $38.533 \mathrm{cde}$ & $17.860 \mathrm{~lm}$ & $0.220 \mathrm{~lm}$ & 10.760 hijk & $2.376 \mathrm{~m}$ \\
\hline Skalnige $\times-18^{\circ} \mathrm{C} \times$ Two weeks & $73.244 \mathrm{ijk}$ & $133.333 \mathrm{c}$ & $174.000 \mathrm{bc}$ & $326.667 \mathrm{hij}$ & 33.800 efgh & 20.953 fghi & 0.278 cdefgh & 8.1861 efghi & $3.018 \mathrm{ij}$ \\
\hline Skalnige $\times-18^{\circ} \mathrm{C} \times$ Four weeks & 75.333 fghi & $130.333 \mathrm{de}$ & $174.333 \mathrm{bc}$ & 360.667 defgh & $34.533 \mathrm{efgh}$ & $21.263 \mathrm{fgh}$ & $0.235 \mathrm{jkl}$ & $11.826 \mathrm{bcd}$ & $2.781 \mathrm{kl}$ \\
\hline Hereford $\times 22^{\circ} \mathrm{C} \times$ Two weeks & 77.833 cdef & $130.333 \mathrm{de}$ & $174.000 \mathrm{bc}$ & $422.000 \mathrm{abc}$ & 31.733 ghi & $19.196 \mathrm{ijkl}$ & 0.279 cdefg & 13.800 hijk & $3.835 \mathrm{de}$ \\
\hline Hereford $\times 22^{\circ} \mathrm{C} \times$ Four weeks & $78.333 \mathrm{cde}$ & $130.333 \mathrm{de}$ & $174.000 \mathrm{bc}$ & $462.000 \mathrm{a}$ & $34.733 \mathrm{efgh}$ & $18.196 \mathrm{kl}$ & 0.289 bcdef & 10.800 ghij & $3.801 \mathrm{de}$ \\
\hline Hereford $\times 4^{\circ} \mathrm{C} \times$ Two weeks & $78.600 \mathrm{cde}$ & $130.000 \mathrm{de}$ & $173.333 \mathrm{c}$ & $398.667 \mathrm{bcd}$ & 37.533 cdefg & 20.897 fghi & $0.327 \mathrm{a}$ & $10.911 \mathrm{~b}$ & $4.546 \mathrm{~b}$ \\
\hline Hereford $\times 4^{\circ} \mathrm{C} \times$ Four weeks & $79.167 \mathrm{cde}$ & $130.000 \mathrm{de}$ & $174.000 \mathrm{bc}$ & 362.000 defgh & 36.533 efg & $18.941 \mathrm{jkl}$ & 0.177 no & 13.943 bcdef & $2.464 \mathrm{~m}$ \\
\hline Hereford $\times-18^{\circ} \mathrm{C} \times$ Two weeks & 75.167 ghi & $130.667 \mathrm{de}$ & $174.000 \mathrm{bc}$ & $448.333 \mathrm{a}$ & $32.178 \mathrm{fgh}$ & 20.368 ghij & $0.185 \mathrm{n}$ & $12.778 \mathrm{bc}$ & $2.353 \mathrm{~m}$ \\
\hline Hereford $\times-18^{\circ} \mathrm{C} \times$ Four weeks & $79.000 \mathrm{cde}$ & $129.000 \mathrm{e}$ & $175.667 \mathrm{~b}$ & 389.000 bcde & $34.400 \mathrm{efgh}$ & $18.380 \mathrm{kl}$ & $0.230 \mathrm{jkl}$ & 13.835 bcdef & $3.182 \mathrm{hi}$ \\
\hline Ritraw $\times 22^{\circ} \mathrm{C} \times$ Two weeks & $79.500 \mathrm{~cd}$ & $132.000 \mathrm{~cd}$ & $174.333 \mathrm{bc}$ & 380.000 cdefg & $42.467 \mathrm{bcd}$ & $27.227 \mathrm{c}$ & 0.247 ghijkl & 12.791 bcde & $3.169 \mathrm{hi}$ \\
\hline Ritraw $\times 22^{\circ} \mathrm{C} \times$ Four weeks & $78.833 \mathrm{cde}$ & $132.000 \mathrm{~cd}$ & $175.000 \mathrm{bc}$ & 383.333 cdefg & $42.800 \mathrm{bc}$ & $27.227 \mathrm{c}$ & $0.241 \mathrm{ijkl}$ & 13.124 cdefg & 3.169hi \\
\hline Ritraw $\times 4^{\circ} \mathrm{C} \times$ Two weeks & 77.500 cdefg & $132.000 \mathrm{~cd}$ & $174.667 \mathrm{bc}$ & 384.000 cdefg & $33.800 \mathrm{efgh}$ & $24.457 \mathrm{~d}$ & 0.284 bcdef & $12.386 \mathrm{defg}$ & $3.515 \mathrm{f}$ \\
\hline Ritraw $\times 4^{\circ} \mathrm{C} \times$ Four weeks & $79.667 \mathrm{c}$ & $130.667 \mathrm{de}$ & $180.333 \mathrm{a}$ & $429.333 \mathrm{ab}$ & $38.033 \mathrm{cdef}$ & $19.175 \mathrm{ijkl}$ & $0.183 n$ & $12.337 \mathrm{efgh}$ & $2.275 \mathrm{~m}$ \\
\hline Ritraw $\times-18^{\circ} \mathrm{C} \times$ Two weeks & $79.833 \mathrm{c}$ & 131.333 cde & $175.667 \mathrm{~b}$ & 353.667 defgh & $36.833 \mathrm{efg}$ & $21.888 \mathrm{efg}$ & 0.166 no & 12.204 fghij & $2.023 \mathrm{n}$ \\
\hline Ritraw $\times-18^{\circ} \mathrm{C} \times$ Four weeks & $77.667 \mathrm{cdefg}$ & $131.667 \mathrm{~cd}$ & $174.333 \mathrm{bc}$ & $287.000 \mathrm{jk}$ & $35.600 \mathrm{efgh}$ & $30.141 \mathrm{~b}$ & $0.195 \mathrm{mn}$ & $11.528 \mathrm{a}$ & $2.245 \mathrm{~m}$ \\
\hline Sabir-beg $\times 22^{\circ} \mathrm{C} \times$ Two weeks & $115.000 \mathrm{a}$ & $102.333 \mathrm{f}$ & $145.000 \mathrm{~d}$ & $290.000 \mathrm{jk}$ & $24.550 \mathrm{jklm}$ & $30.477 \mathrm{~b}$ & $0.301 \mathrm{abcd}$ & $15.878 \mathrm{a}$ & $4.790 \mathrm{a}$ \\
\hline Sabir-beg $\times 22^{\circ} \mathrm{C} \times$ Factor-3-C2 & $115.333 \mathrm{a}$ & $102.333 \mathrm{f}$ & $145.000 \mathrm{~d}$ & $286.000 \mathrm{jk}$ & $24.550 \mathrm{jklm}$ & $30.477 \mathrm{~b}$ & 0.294 abcde & $16.261 \mathrm{a}$ & $4.790 \mathrm{a}$ \\
\hline Sabir-beg $\times 4^{\circ} \mathrm{C} \times$ Two weeks & $115.167 \mathrm{a}$ & $101.667 \mathrm{f}$ & $145.333 \mathrm{~d}$ & 351.333 efghi & $22.500 \mathrm{klm}$ & $32.721 \mathrm{a}$ & 0.258 fghijk & $15.946 \mathrm{a}$ & $4.121 \mathrm{c}$ \\
\hline Sabir-beg $\times 4^{\circ} \mathrm{C} \times$ Four weeks & $116.000 \mathrm{a}$ & $101.667 \mathrm{f}$ & $145.000 \mathrm{~d}$ & 388.000 bcdef & $19.333 \mathrm{~m}$ & $31.648 \mathrm{ab}$ & 0.261 efghij & $15.320 \mathrm{a}$ & $4.004 \mathrm{~cd}$ \\
\hline Sabir-beg $\times-18^{\circ} \mathrm{C} \times$ Two weeks & $111.833 \mathrm{~b}$ & $101.333 \mathrm{f}$ & $145.000 \mathrm{~d}$ & $308.000 \mathrm{ij}$ & $20.133 \mathrm{~lm}$ & $31.264 \mathrm{ab}$ & $0.224 \mathrm{klm}$ & $15.495 \mathrm{a}$ & $3.468 \mathrm{fg}$ \\
\hline Sabir-beg $\times-18^{\circ} \mathrm{C} \times$ Four weeks & $115.833 \mathrm{a}$ & $102.333 \mathrm{f}$ & $145.000 \mathrm{~d}$ & $291.667 \mathrm{jk}$ & $24.733 \mathrm{jklm}$ & $31.203 \mathrm{ab}$ & $0.243 \mathrm{ijkl}$ & $15.635 \mathrm{a}$ & $3.801 \mathrm{de}$ \\
\hline
\end{tabular}




\section{Conclusion}

The wheat varieties had a highly significant variance for all the studied traits. Sabir-beg had the highest and most desired performance for most of the traits including grain yield, while Hereford had the highest spike number per unit area, and Skalnige showed the highest grain number/spike. The incubation temperatures had a highly significant effect on most of the traits including grain yield. Days to flowering was reduced with $-18^{\circ} \mathrm{C}$ incubation. The same pattern was also indicated for days to maturity, spending less days to maturity when vernalized at $-18^{\circ} \mathrm{C}$ treatment.

Period of incubation for different temperatures had a significant effect on plant height, days to maturity, and 1000 kernel weight. This result indicates the satisfaction period of two weeks incubation at low temperature for the wheat varieties. Sabir-beg is a local variety that is mostly adapted to the local environment, requiring less vernalization, as the interaction effect of this variety at low incubation temperature had less effect on the studied traits.

The interaction of varieties $\times$ incubation temperature had a highly significant effect on all traits except biomass yield. The interaction of $4^{\circ} \mathrm{C}$ with different wheat varieties had superiority to direct some of the important traits. It also seems that grain number is mainly genotype-related as the incubation treatment has no significant effect on the improvement of this trait. This result assured the necessity of involving the European varieties in field trials to be used directly or in a breeding program to improve the grain number/spike as an important trait related to yield. The high number of 40.566 grain/spike for Skalnige variety compared to 22.633 grain/spike of local variety is a big support for the importance of involving the European variety in the improvement program of wheat in the Kurdistan region of Iraq. The varieties persistency is also an outcome of their interaction with the incubation period, as the incubation of four weeks period had no recognized change on the traits compared to the two weeks incubation. The interaction effect of $4^{\circ} \mathrm{C} \times$ four weeks period had allowed the flowering to be advanced, allowing the plant to stay longer in the flowering and maturation period giving a higher number of spike per unit area, which indicates the effect of low incubation temperature on the varieties under local environmental conditions.

Both interactions of varieties $\times$ incubation temperature and varieties $\times$ incubation period had a similar effect on the traits studied, as harvest index, biomass yield, and grain yield were highly significant for both interactions, but with less effect on improving the yield. This could refer to the availability of different alleles for VRNI gene, reducing the necessity of vernalization period or reversing its effect. Cold treatment (vernalization) can not alone regulate the flowering initiation, coordinating the responsive interaction of the plant with its environment, it is also necessary to express floral activation. The interaction of all three factors showed a highly significant effect on all the traits. Cultivation of the European varieties under study under local environmental conditions is recommended to boost the increase of grain yield in wheat. In vitro vernalization for the grains is a substitute solution for completing the required vernalization period, that might be raised by delaying sowing or unsatisfied cold period during planting and growing season to vernalize such varieties. Further filed trial is suggested in the future, involving more variable wheat genotypes to evaluate the yield resiliency and homeostasis of broad and diverse alleles under local environmental conditions. 
Acknowledgments. The authors are grateful for the Department of Biotechnology and Crop Science, the University of Sulaimani for providing all facilities and for providing land to conduct the research.

\section{REFERENCES}

[1] Ali, Sh. S., Ahmad, N. S., Ahmad, M. M., Ahmad, D. A. (2018): Performance of Bread Wheat (Triticum aestivum L.) Varieties under Rainfed Condition of Sulaimani. - Journal of Zankoy Sulaimani Part-A 20(3-4): 29-36.

[2] Armonienè, R., Liatukas, Ž., Brazauskas, G. (2013): Evaluation of freezing tolerance of winter wheat (Triticum aestivum L.) under controlled conditions and in the field. Žemdirbystè (Agriculture) 100(4): 417-424.

[3] Asseng, S., Ewert, F., Martre, P., Rötter, R. P., Lobell, D. B., Cammarano, D., Kimball, B. A., Ottman, M. J., Wall, G. W., White, J. W., Reynolds, M. P. (2015): Rising temperatures reduce global wheat production. - Nature climate change 5(2): 143.

[4] Brinton, J., Simmonds, J., Minter, F., Leverington-Waite, M., Snape, J., Uauy, C. (2017): Increased pericarp cell length underlies a major quantitative trait locus for grain weight in hexaploid wheat. - New Phytologist 215(3): 1026-1038.

[5] Chen, F., Gao, M., Zhang, J., Zuo, A., Shang, X., Cui, D. (2013): Molecular characterization of vernalization and response genes in bread wheat from the Yellow and Huai Valley of China. - BMC plant biology 13(1): 199.

[6] Chouard, P. (1960): Vernalization and its relations to dormancy. - Annual Review of Plant Physiology 11(1): 191-238.

[7] Clay, D. E., Carlson, C. G., Dalsted, K. (2012): IGrow Wheat: Best Management Practices for Wheat Production. - South Dakota State University, College of Agriculture and Biological Sciences.

[8] Crofts, H. (1989): On defining a winter wheat. - Euphytica 44(3): 225-234.

[9] Dixon, L. E., Karsai, I., Kiss, T., Adamski, N. M., Liu, Z., Ding, Y., Allard, V., Boden, S. A., Griffiths, S. (2019): VERNALIZATION1 controls developmental responses of winter wheat under high ambient temperatures. - Development 146(3): dev172684.

[10] Galiba, G., Vágújfalvi, A., Li, C., Soltész, A., Dubcovsky, J. (2009): Regulatory genes involved in the determination of frost tolerance in temperate cereals. - Plant Science 176(1): 12-19.

[11] Goncharov, N. P. (2004): Response to vernalization in wheat: its quantitative or qualitative nature. - Cereal Research Communications 32(3): 323-330.

[12] Gott, M. B., Gregory, F. G., Purvis, O. (1955): Studies in Vernalisation of Cereals: XIII. Photoperiodic Control of Stages in Flowering between Initiation and Ear Formation in Vernalised and Unvernalised Petkus Winter Rye. - Annals of Botany 19(1): 87-126.

[13] Griffiths, F. E., Lyndon, R., Bennett, M. (1985): The effects of vernalization on the growth of the wheat shoot apex. - Annals of Botany 56(4): 501-511.

[14] Griffiths, S., Simmonds, J., Leverington, M., Wang, Y., Fish, L., Sayers, L., Alibert, L., Orford, S., Wingen, L., Herry, L., Faure, S. (2009): Meta-QTL analysis of the genetic control of ear emergence in elite European winter wheat germplasm. - Theoretical and Applied Genetics 119(3): 383-395.

[15] Guo, J., Zhang, Y., Shi, W., Zhang, B., Zhang, J., Xu, Y., Cheng, X., Cheng, K., Zhang, X., Hao, C., Cheng, S. (2015): Association analysis of grain-setting rates in apical and basal spikelets in bread wheat (Triticum aestivum L.). - Frontiers in plant science 6: 1029.

[16] Heide, O. M., Sønsteby, A. (2015): Dormancy Interferes with Flowering in Perennial Plants with Short Day Regulation of Both Processes: A Mini-Review. - Agricultural Sciences 6(8): 778.

[17] Hemming, M. N., Peacock, W. J., Dennis, E. S., Trevaskis, B. (2008): Low-temperature and daylength cues are integrated to regulate FLOWERING LOCUS T in barley. - Plant Physiology 147(1): 355-366. 
[18] Kazan, K., Lyons, R. (2014): Intervention of phytohormone pathways by pathogen effectors. - The Plant Cell 26(6): 2285-2309.

[19] Kim, D. H., Doyle, M. R., Sung, S., Amasino, R. M. (2009): Vernalization: winter and the timing of flowering in plants. - Annual Review of Cell and Developmental 25: 277-299.

[20] Kippes, N., Debernardi, J. M., Vasquez-Gross, H. A., Akpinar, B. A., Budak, H., Kato, K., Chao, S., Akhunov, E., Dubcovsky, J. (2015): Identification of the VERNALIZATION 4 gene reveals the origin of spring growth habit in ancient wheats from South Asian. Proceedings of the National Academy of Sciences 112(39): 5401-5410.

[21] Kumar, A., Mantovani, E., Seetan, R., Soltani, A., Echeverry-Solarte, M., Jain, S., Simsek, S., Doehlert, D., Alamri, M. S., Elias, E. M., Kianian, S. F. (2016): Dissection of genetic factors underlying wheat kernel shape and size in an elite $\times$ nonadapted cross using a high density SNP linkage map. - Plant Genome 9(1). doi: 10.3835/plantgenome2015.09.0081.

[22] Levy, J., Peterson, M. L. (1972): Responses of spring wheats to vernalization and photoperiod. - Crop Science 12(4): 487-490.

[23] Li, C., Dubcovsky, J. (2008): Wheat FT protein regulates VRN1 transcription through interactions with FDL2. - The Plant Journal 55(4): 543-554.

[24] Li, G., Yu, M., Fang, T., Cao, S., Carver, B. F., Yan, L. (2013): Vernalization requirement duration in winter wheat is controlled by T a VRN-A 1 at the protein level. - The Plant Journal 76(5): 742-753.

[25] McMaster, G., Wilhelm, W. (2003): Phenological responses of wheat and barley to water and temperature: improving simulation models. - The Journal of Agricultural Science 141(2): 129-147.

[26] Michaels, S. D. (2009): Flowering time regulation produces much fruit. - Current opinion in plant biology 12(1): 75-80.

[27] Mureşan, D., Kadar, R., Ghețe, A., Duda, M., Mureşan, C. (2019): Vernalization of Wheat and Genetic Determinism of the Vernalization Reaction. - ProEnvironment 12: 170-176.

[28] Muterko, A., Salina, E. (2018): Origin and distribution of the VRN-A1 exon 4 and exon 7 haplotypes in domesticated wheat species. - Agronomy 8(8): 156.

[29] Ortiz-Ferrara, G., Mosaad, M., Mahalakshmi, V., Fischer, R. (1995): Photoperiod and vernalization response of wheat under controlled environment and field conditions. - Plant Breeding 114(6): 505-509.

[30] Robertson, M., Brooking, I., Ritchie, J. (1996): Temperature response of vernalization in wheat: modelling the effect on the final number of mainstem leaves. - Annals of Botany 78(3): 371-381.

[31] Rozbicki, J., Gozdowski, D., Studnicki, M., Mądry, W., Golba, J., Sobczyński, G., Wijata, M. (2019): Management intensity effects on grain yield and its quality traits of winter wheat cultivars in different environments in Poland. - Biotechnology 22(1): 02.

[32] Searle, I., Coupland, G. (2004): Induction of flowering by seasonal changes in photoperiod. - The EMBO Journal 23(6): 1217-1222.

[33] Sharma, S., Sharma, R., Chaudhary, H. (2012): Vernalization response of winter x spring wheat derived doubled-haploids. - African Journal of Agricultural Research 7(48): 64656473.

[34] Shewry, P. R. (1998): Seed Biology and the Yield of Grain Crops. Dennis B. Egli. - Plant Growth Regulation 26(2): 140-141.

[35] Shourbalal, S. K. S., Soleymani, A., Javanmard, H. R. (2019): Shortening vernalization in winter wheat (Triticum aestivum L.) using plant growth regulators and cold stratification. - Journal of Cleaner Production 219: 443-450.

[36] Slafer, G. (2003): Genetic basis of yield as viewed from a crop physiologist's perspective. - Annals of Applied Biology 142(2): 117-128.

[37] Trevaskis, B. (2010): The central role of the VERNALIZATION1 gene in the vernalization response of cereals. - Functional Plant Biology 37(6): 479-487. 
[38] Wang, S. Y., Ward, R. W., Ritchie, J. T., Fischer, R. A., Schulthess, U. (1995): Vernalization in wheat II. Genetic variability for the interchangeability of plant age and vernalization duration. - Field Crops Research 44(2-3): 67-72.

[39] Whittal, A., Kaviani, M., Graf, R., Humphreys, G., Navabi, A. (2018): Allelic variation of vernalization and photoperiod response genes in a diverse set of North American high latitude winter wheat genotypes. - Plos One 13(8): e0203068-e0203068.

[40] Woods, D., Dong, Y., Bouche, F., Bednarek, R., Rowe, M., Ream, T., Amasino, R. (2019): A florigen paralog is required for short-day vernalization in a pooid grass. - eLife 8: e42153.

[41] Yan, L., Fu, D., Li, C., Blechl, A., Tranquilli, G., Bonafede, M., Sanchez, A., Valarik, M., Yasuda, S., Dubcovsky, J. (2006): The wheat and barley vernalization gene VRN3 is an orthologue of FT. - Proceedings of the National Academy of Sciences 103(51): 1958119586.

[42] Yan, L., Li, G., Yu, M., Fang, T., Cao, S., Carver, B. F. (2015): Genetic mechanisms of vernalization requirement duration in winter wheat cultivars. - In: Ogihara, Y., Takumi, S., Handa, H. (eds.) Advances in Wheat Genetics: From Genome to Field. Springer, Tokyo, pp. 117-125.

[43] Yong, W. D., Xu, Y. Y., Xu, W. Z., Wang, X., Li, N., Wu, J. S., Liang, T. B., Chong, K., Xu, Z. H., Tan, K. H., Zhu, Z. Q. (2003): Vernalization-induced flowering in wheat is mediated by a lectin-like gene VER2. - Planta 217(2): 261-270. 